\title{
北海道日高地方に於けろ甲狀腺腫地帶区 天然水中の弗素濃度について
}

\author{
高昌英彦 \\ (北海道大学医学部薬理学教室 (主任 真崎煡夫教授》) \\ (明和 32 年11月12日受付)
}

\begin{abstract}
粕
言

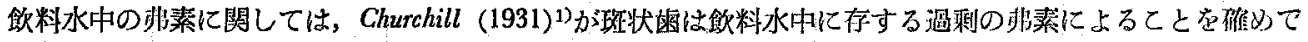
以来広く研究される滕になり，地方的に韭常に大量の非素を含む飲料水が使用されているてとが判って来た．北

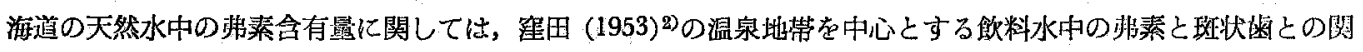
尾についての報告があるが，てれらの内には日高地力は含まれていない，又一方，甲状腺嗹が地万病的に存在す

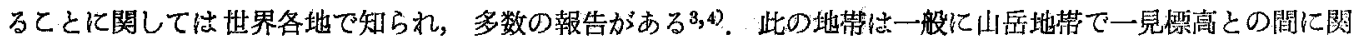

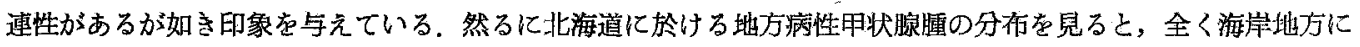
限局している点特異的で，沃度欠乏が全く考元られない地方であるから沃度欠乏によっては説明か困難である。

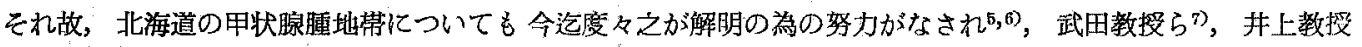
ら゙) の詳細な報告がある。

私は実地調查で日高地方の甲状腺婳地带が比較的狭い区域に局限されて散在するてとに気附いた．そして日

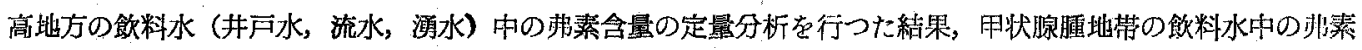
含有量が多いてとを知つたので報告する次第である。
\end{abstract}

\section{弗素定量法}

寉田の Zirconium-alizarin の改良法杰を用いた。 即ち, Zirconium-nitrate 0.2gt50ccの Aq. dest. 亿溶解，

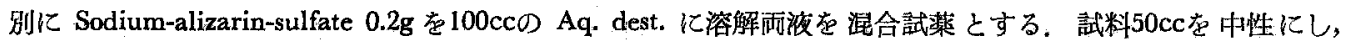

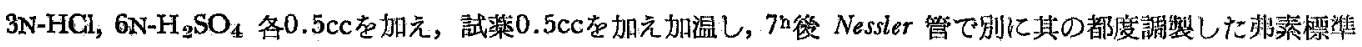
波と比色定量した．本法心非常に敏感で，最低限界 $0.001 \mathrm{mg} / 50 \mathrm{cc}(0.02 \mathrm{p} . \mathrm{p} . \mathrm{m}$. 溶液に相当する)て，他の方法よ りすぐれている，私の定量した飲料水では Willard \& Winter の Hydro-Aluosilicic acid distillated method ${ }^{9)}$ 年 使用する必要はなかった。

\section{実 験 成 績}

\section{1) 饮料水中の弗素含有量}

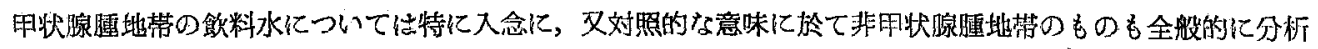

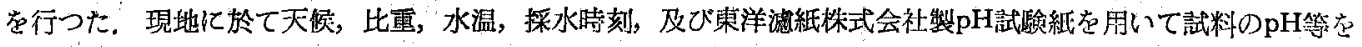

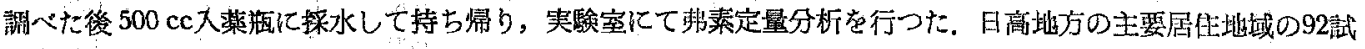
劉水についての分析結果虻表の加くであつた，最高含有量 0.35p.p.m. で一般には 0.1p.p.m. 質後であつた，砄 
第 1 表. 日高地方隹於ける天然水中の弗瑟含有量.

\begin{tabular}{|c|c|c|c|c|c|c|c|c|}
\hline No. & 採 水 皦 站 & 㨲水月日 & 時刻 & 天候 & 比重 & $\begin{array}{l}\text { 水温 } \\
\left({ }^{\circ} \mathrm{C}\right)\end{array}$ & $\mathrm{pH}$ & $\begin{array}{c}\bar{F} \\
\text { p.p.m. }\end{array}$ \\
\hline 1 & 門别川流水（附则槜） & 30.3 .16 & 14.10 & 䦎。 & 1000 & 4 & 4.4 & 0.175 \\
\hline 2 & 阴别町水道水 & $30.3 .16^{*}$ & 14.00 & $" 1$ & 1000 & 6 & 4.0 & 0.075 \\
\hline 3 & 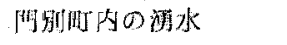 & 30.3 .16 & 13.50 & $" 1$ & 1000 & 5 & 4.4 & 0.175 \\
\hline 4 & 沙流川流水（䀂川樗） & 30.3 .16 & 12.00 & 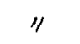 & 1000 & 3 & 4.0 & 0.175 \\
\hline 5 & 富川用内の湧水 & 30.3 .16 & 11.40 & $"$ & 1000 & 7 & 4.2 & 0.15 \\
\hline 6 & 平取村内の井五水 & 30.3 .16 & 9.00 & " & 1000 & 8 & 4.0 & 0.25 \\
\hline 7 & 平取村内㵢水 & 30.3 .16 & 9.10 & $" \prime$ & 1000 & 7 & 4.0 & 0.20 \\
\hline 8 & 沙流川流水（层肑橋） & 30.3 .15 & 15.10 & $" \prime$ & 1000 & 3 & 4.4 & 0.25 \\
\hline 9 & 振内橋附近の湧水 & 30.3 .15 & 15.20 & 11 & 1000 & 6 & 4.2 & 0.15 \\
\hline 10 & 振内村内非戸水 & 30.3 .15 & 15.40 & $"$ & 1000 & 5 & 4.2 & 0.2 \\
\hline 11 & 掌賀村内の流水 & 30.3 .15 & 10.15 & " & 1000 & 4 & 4.2 & 0.25 \\
\hline 12 & 䉼冠川流水（新冠橋） & 30.3 .15 & 8.25 & $\prime \prime$ & 1000 & 2 & 4.8 & 0.15 \\
\hline 13 & 新冠村内北戸水 & 30.3 .15 & 8.55 & $" 1$ & 1000 & 8 & 4.0 & 0.05 \\
\hline 14 & 䉼㱏村内涌水 & 30.3 .15 & 9.10 & $"$ & 1000 & 8 & 4.2 & 0.025 \\
\hline 15 & 静内川流水（静内橋） & 30. 2.8 & 14.15 & "1 & 1000 & 6 & 5.2 & 0.175 \\
\hline 16 & 請将内町井戸水 & 30. 2.8 & 14.25 & $"$ & 1000 & 7 & 5.0 & 0.05 \\
\hline 17 & 東静内井户水 & 30.2 .8 & 15.40 & $"$ & 1000 & 8 & 4.8 & 0.35 \\
\hline 18 & 三石川流水（三石橋） & 30. 2.9 & 8.30 & $"$ & 1000 & 8 & 5.0 & 0.15 \\
\hline 19 & 三石町内井戸水 & 30. 2.9 & 8.00 & $"$ & 1000 & 8 & 4.8 & 0.15 \\
\hline 20 & 三石町内勈水 & 30. 2.9 & 8.25 & " & 1000 & 9 & 5.0 & 0.35 \\
\hline 21 & 狄伏川流水（荻伏橋） & 30. 2.9 & 13.00 & " & 1000 & 9 & 5.0 & 0.25 \\
\hline 22 & 狄伏村内涌水 & 30.2 .9 & 13.10 & $" 1$ & 1000 & 9 & 5.2 & 0.325 \\
\hline 23 & 浦河堺町小流水 & 30.1 .13 & 13.25 & $"$ & 1000 & 7 & 5.6 & 0.0 \\
\hline 24 & 浦河町内扑水 & 30.1 .13 & 13.35 & " & 1000 & 6 & 5.2 & 0.025 \\
\hline 25 & 浦河町水道水 & 30.1 .13 & 13.45 & "y & 1000 & 6 & 5.0 & 0.2 \\
\hline 26 & 浦河町乳吞小流水 & 30.1 .13 & 13.40 & $" 1$ & 1000 & 6 & 5.6 & 0.3 \\
\hline 27 & 日漓月寒川流水 & 30. 1.21 & 14.35 & " & 1000 & 8 & 5.0 & 0.35 \\
\hline 28 & 日高月寒村内井戸水 & 30.1 .21 & 14.55 & $"$ & 1000 & 6 & 5.2 & 0.35 \\
\hline 29 & 日高月寒村内㩖水 & 30. 1.21 & 14.10 & $"$ & 1000 & 5 & 5.2 & 0.3 \\
\hline 30 & 覕島流水 & 30.1 .21 & 13.50 & $"$ & 1000 & 5 & 5.6 & 0.2 \\
\hline 31 & 白泉村内投戸水（1) & 30.1 .27 & 10.40 & "I & 1000 & 13 & 4.8 & 0,15 \\
\hline 32 & 白泉村内扑戸水 (2) & 30.1 .27 & 10.30 & 雪 & 1000 & 14 & 5.2 & 0.35 \\
\hline 33 & 日哃幌別川流水 & 30. 1.23 & 14,20 & $" \prime$ & 1000 & 5 & 5.2 & 0.125 \\
\hline 34 & 日商帽別村内小流水 & 30.1 .23 & 14.30 & $" \prime$ & 1000 & 2 & 5.6 & 0.175 \\
\hline 35 & 鵜苫川流水 & 30.1 .23 & 14.55 & $"$ & 1000 & 2 & 5.2 & 0.25 \\
\hline 36 & 鴾菬村内非戸水（1） & 30.1 .23 & 15.10 & $"$ & 1000 & 6 & 4.8 & 0.175 \\
\hline 37 & 鴠苫村内将戸水（2) & 30.1 .23 & 15.25 & 11 & 1000 & 9 & 5.2 & 0.05 \\
\hline 38 & 西橔似演水（隧道） & 30.1 .23 & 15.55 & $\prime \prime$ & 1000 & 7 & 5.0 & 0.1 \\
\hline 39 & 西様似井示水 & 30.1 .23 & 12.00 & 11 & 1000 & 7 & 5.2 & 0.15 \\
\hline 40 & 西㥞似銥泉水 & 29.12 .16 & 16.10 & 霹 & 1002 & 5 & 5.2 & 0.125 \\
\hline 41 & 西様似湧水 & 29.12 .16 & 12.10 & $\prime \prime$ & 1000 & 8 & 5.0 & 0.025 \\
\hline 42 & 西樣似流水 & 29.12 .16 & 12.30 & $" \prime$ & 1000 & 3 & 5.0 & 0.1 \\
\hline 43 & 様似盯内非戸水（1） & 29.12 .17 & 14.05 & " & 1000 & 7 & 5.2 & 0.1 \\
\hline 44 & 11 & 29.12 .15 & 12.15 & $"$ & 1000 & 6 & 4.8 & 0.025 \\
\hline 45 & (3) & 29.12 .15 & 14.10 & 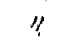 & 1000 & 7 & 5.0 & 0.15 \\
\hline
\end{tabular}




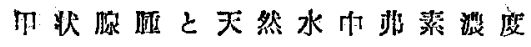

\begin{tabular}{|c|c|c|c|c|c|c|c|c|}
\hline 46 & 様似町内涌水 & 29.12 .16 & 16.10 & 晴 & 1000 & 8 & 5.6 & 0.05 \\
\hline 47 & 様似川流水（様似橋） & 29.12 .15 & 14.30 & $" 1$ & 1000 & 4 & 5.0 & 0.2 \\
\hline 48 & 様似朾水道水 & 29.12 .16 & 13.00 & $" \prime$ & 1000 & 10 & 5.0 & 0.15 \\
\hline 49 & 東様似小流水 & 29.12 .17 & 15.00 & $"$ & 1000 & 3 & 4.6 & 0.125 \\
\hline 50 & 東樣似井戸水 & 29.12 .17 & 14.40 & $" \prime$ & 1000 & 8 & 5.6 & 0.15 \\
\hline 51 & 樣似町田代小流水 & 29.12 .17 & 12.40 & $" 1$ & 1000 & 4 & 5.0 & 0.125 \\
\hline 52 & 樣似町岡田井戸水 & 29.12 .17 & 12.25 & " & 1000 & 8 & 5.6 & 0.05 \\
\hline 53 & 東样似，工場私設水道水 & 29.12 .15 & 14.50 & $"$ & 1000 & 7 & 5.6 & 0.1 \\
\hline 54 & 平宇川流水 & 29.12 .18 & 15.25 & " & 1000 & 4 & 5.2 & 0.025 \\
\hline 55 & 平宇村内井戸水 & 29.12 .18 & 15.00 & $"$ & 1000 & 8 & 5.0 & 0.0 \\
\hline 56 & 冬島川流水 & 29.12 .18 & 14.45 & $"$ & 1000 & 3 & 5.0 & 0.075 \\
\hline 57 & 冬島井戸水 & 29.12 .18 & 15.35 & " & 1000 & 6 & 5.2 & 0.125 \\
\hline 58 & 東冬島涌水 & 29.12 .18 & 14.30 & " & 1000 & 8 & 5.2 & 0.025 \\
\hline 59 & 山中（小川I）流水 (1) & 29.12 .18 & 14.00 & " & 1000 & 3 & 5.0 & 0.25 \\
\hline 60 & $" 1$ & 29.12 .18 & 14.10 & " & 1000 & 2 & 5.8 & 0.25 \\
\hline 61 & 山中涌水（1） & 29.12 .25 & 14.30 & " & 1000 & 4 & 5.6 & 0.125 \\
\hline 62 & $" 1 \quad(2)$ & 29.12 .25 & 14.50 & $" 1$ & 1000 & 2 & 5.6 & 0.1 \\
\hline 63 & 沅満川流水（幌满橋） & 29.12 .21 & 15.05 & 雱 & 1000 & 2 & 5.0 & 0.1 \\
\hline 64 & 兒蒴村内井戸水（1） & 29.12 .21 & 14.40 & " & 1000 & 6 & 5.2 & 0.175 \\
\hline 65 & $\prime \prime$ & 29.12 .21 & 14.00 & " & 1000 & 9 & 5.2 & 0.175 \\
\hline 66 & 旭村队涌水 & 29.12 .21 & 13.10 & $"$ & 1000 & 3 & 5.2 & 0.125 \\
\hline 67 & 旭村内流水 & 29.12 .21 & 13.20 & $"$ & 1000 & 6 & 5.6 & 0.175 \\
\hline 68 & 下笛舞小流水（1） & 30.1 .27 & 14.55 & 晴 & 1060 & 6 & 5.0 & 0.2 \\
\hline 69 & $11 \quad(2)$ & 30.1 .27 & 15.15 & " & 1000 & 6 & 4.8 & 0.25 \\
\hline 70 & 日勝大和川流水 & 30.1 .27 & 15.00 & " & 1000 & 6 & 5.0 & 0.2 \\
\hline 71 & 日勝大和村内井戸水 & 30.1 .27 & 14.30 & $" 1$ & 1000 & 5 & 4.8 & $\mathbf{0 . 3}$ \\
\hline 72 & 唓泉川流水 & 30.1 .8 & 9.00 & $"$ & 1000 & 2 & 5.2 & 0.25 \\
\hline 73 & 幌泉村内井户水（1） & 30.1 .8 & 9.55 & " & 1000 & 5 & 5.6 & 0.125 \\
\hline 74 & II & 30.1 .8 & 13.00 & $"$ & 1000 & 5 & 5.2 & 0.075 \\
\hline 75 & 東洋小流水 & 30.1 .8 & 13.45 & "y & 1000 & 2 & 5.6 & 0.35 \\
\hline 76 & 東洋村内井戸水 & 30.1 .8 & 13.55 & $"$ & 1000 & 10 & 5.0 & 0.15 \\
\hline 77 & 庶野村内小流水（1） & 30.1 .19 & 10.45 & " & 1000 & 4 & 5.6 & 0.125 \\
\hline 78 & $\prime \prime \quad(2)$ & 30. 1.19 & 10.25 & $" 1$ & 1000 & 4 & 5.0 & 0.25 \\
\hline 79 & 鷿野村内井戸水（1） & 30.1 .19 & 10.15 & " & 1000 & 8 & 5.2 & 0.05 \\
\hline 80 & $\prime \prime \quad(2)$ & 30.1 .19 & 10.55 & $"$ & 1000 & 7 & 4.8 & 0.1 \\
\hline 81 & 筀裳村内井戸水 (1) & 30.7 .12 & 9.00 & $" 1$ & 1000 & 20 & 4.4 & 0.2 \\
\hline 82 & $" \prime$ & 30.7 .12 & 9.30 & $" \prime$ & 1000 & 15 & 4.8 & 0.125 \\
\hline 83 & (3) & 30. 7.12 & 9.40 & $" 1$ & 1000 & 19 & 4.4 & 0.25 \\
\hline 84 & (4) & 30.7 .12 & 9.50 & $" 1$ & 1000 & 19 & 4.8 & 0.25 \\
\hline 85 & $" 1$ & 30.7 .12 & 10.05 & $"$ & 1000 & 18 & 4.8 & 0.3 \\
\hline 86 & 歌別村内井户水 & 30.7 .12 & 10.50 & $"$ & 1000 & 15 & 5.2 & 0.15 \\
\hline 87 & 歌別水流水 & 30.7 .12 & 13.30 & $"$ & 1000 & 18 & 4.8 & 0.2 \\
\hline 88 & 日勝目黒流水 & 30.7 .13 & 8.45 & $"$ & 1000 & 18 & 4.8 & 0.1 \\
\hline 89 & 日勝目量井戸水 (1) & 30.7 .13 & 11.35 & $"$ & 1000 & 19 & 4.8 & 0.25 \\
\hline 90 & II (2) & 30.7 .13 & 11.55 & $"$ & 1000 & 16 & 4.4 & 0.25 \\
\hline 91 & 油駒小流水 & 30.7 .13 & 12.05 & $"$ & 1000 & 22 & 4.8 & 0.2 \\
\hline 92 & 目黑村内漖水 & 30. 7.13 & 12,20 & $"$ & 1000 & 18 & 4.8 & 0.3 \\
\hline
\end{tabular}




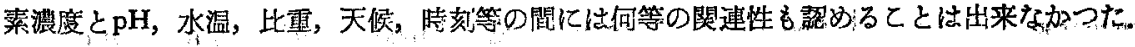

\section{2) 日高地方の甲状腺腫地带の分布}

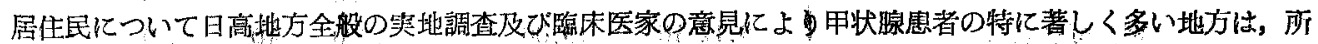

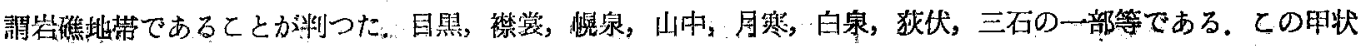

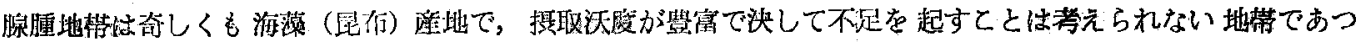
た(図参照)。

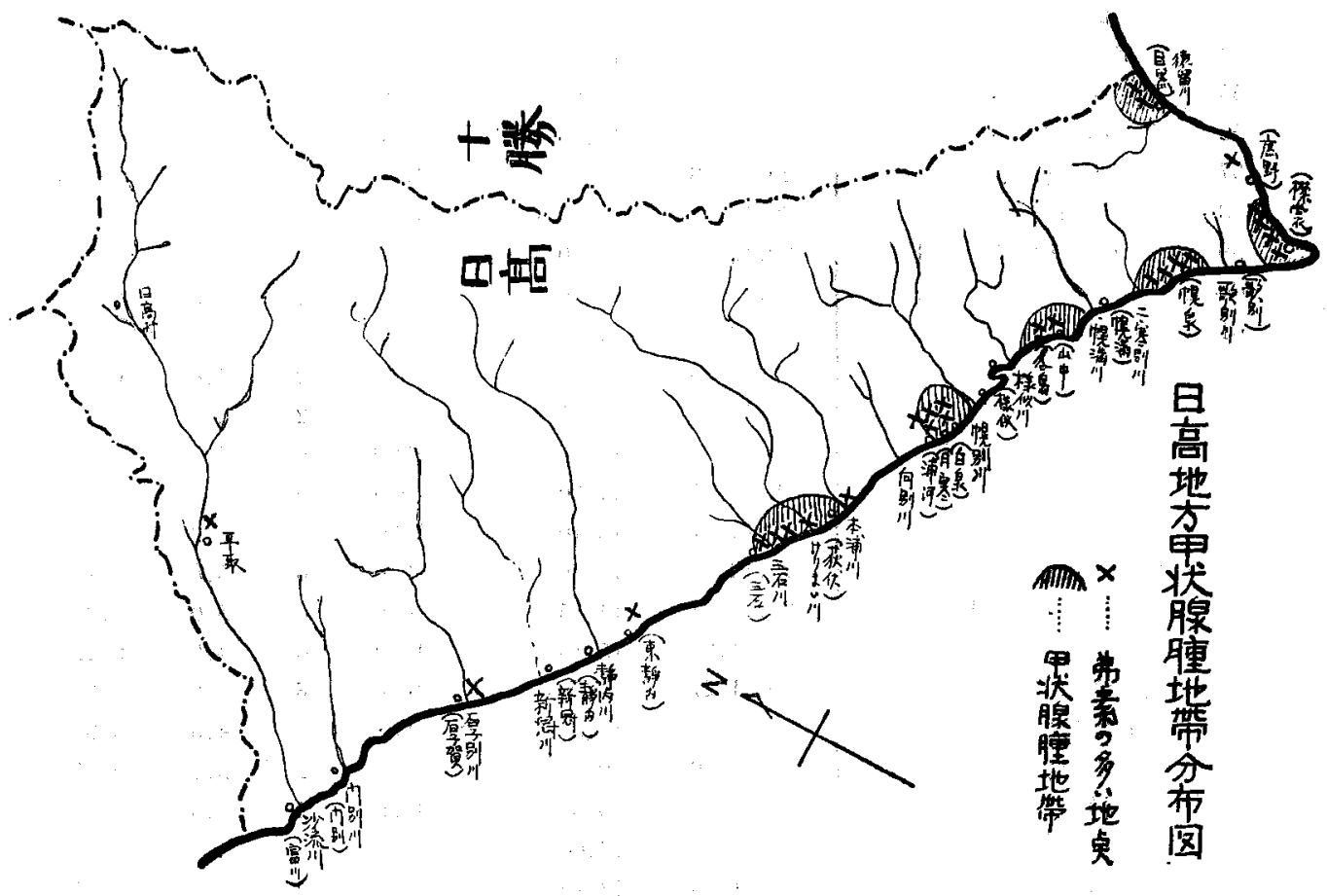

第 1 図. 日高地方甲状腺腯地带分布威。

\section{粉括及び考按}

弗素に関して心特に函科関係者により広く且多数の報告がなされている．私の日高地方の飲料水中の弗素合 有量の分析結果は最高 0.35p.p.m. で，大半は 0.1 p.p.m. 前後及びそれ以下であつて，㴶田の報告と全く一致し t.

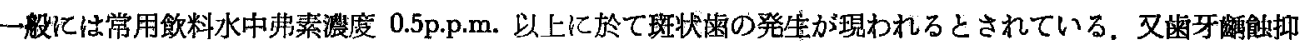

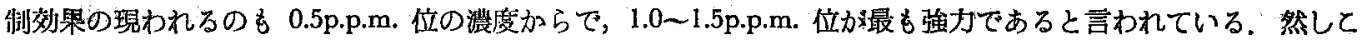

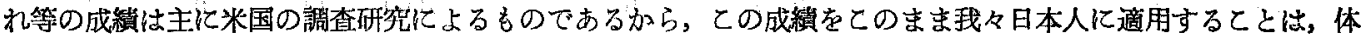
格及び食生活の非常に異る点加ら 尚疑閵が持たれ，日本に於ける领料水への弗素添加も米国より稍々少なく 0.6 p.p.m. を採用している。

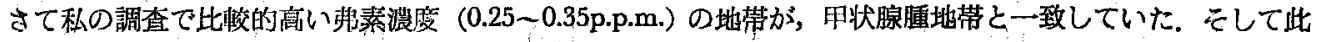
の地带は不思議にも海藻（屁布）産地で，平地か殆んどなく山が海岸位迫り岩礁地带をなしている.

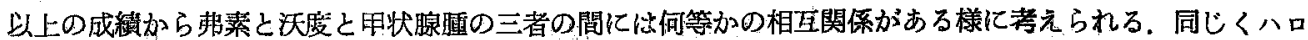

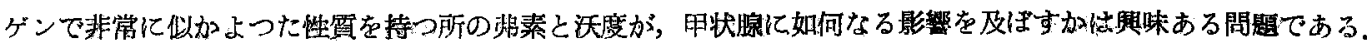

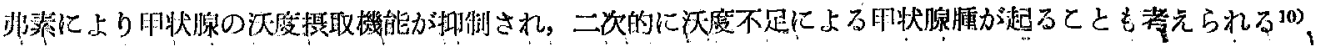


文沃度欠乏によると考えられている甲状腺樋発生原因説に対しても亦疑品が生机る。乙れら地方病性甲状腺 腫地带が一一次的沃度の不足，或は抗甲状腺㓮其の他の原因に上る二次的沃度不足が起り易い地方であると结考光 難いととから，飲料水中の弗素との関連に於てより新しい解釈が必要となるのではないかと考える。

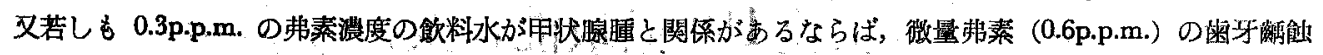
予防效果の故をもつて，弗素を凡ての地方の飲料水中に入れることには賛同するわけに行かないととになる。

\section{結 論}

1. 北海道日高地方全域の敛料水について，窪田の Zirconium-alizarin 政良法を使用して弗秦の定量分析を 行つた.

2. 日高地方の领料水中の弗菜含有量は 0.35p.p.m. が最高で各地䎲分散し，其の他の多くの地域では 0.1 p.p.m. 前後であつた.

3. 日高地方の甲状腚腫地带を調查した。

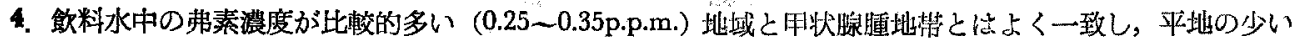
岩礁地帯で海藻（尾布）産地帯でもあつた.

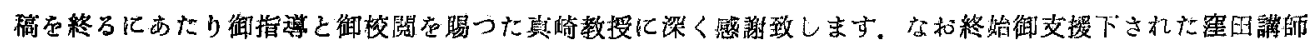
に感謝します。

\section{引用: 文 献}

1) Churchill : Goodman \& Gilman: The Pharmacological Basis of Therapeutics, Macmillan, New York (1955) 飞よる。

2）害田：口腔病学会誌 20，259 (1953).

3) 小谷 : 北関東医学 5, 225 (1955),

4) 七条万：臨床内小 10, 149 (1955).

5) 恩村 万：日病理誌 44, 111 (1955).

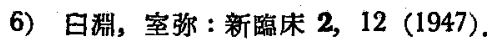

7) 武田 5 : 北海道医学䊒誌 20, 129 (1942).

8) 井上万: 風誌 29, 223 (1954).

9) Willard \& Winter : Ind. Eng. Chem. Anal. Ed. 5, 7 (1933).

10)高田: 末発表. 